PLPB: Pendidikan Lingkungan dan Pembangunan Berkelanjutan

DOI: https://doi.org/10.21009/PLPB.181.05

DOI: 10.21009/PLPB

\title{
RELATIONSHIP BETWEEN KNOWLEDGE ABOUT CLIMATE CHANGE ISSUES AND LOCUS OF CONTROL WITH STUDENTS' CITIZENSHIP BEHAVIOR
}

\author{
Erian Fatria \\ Mahasiswa Prodi PKLH S2 Pascasarjana UNJ \\ erianfatria93@gmail.com
}

\begin{abstract}
Needless to say that environmental deterioration is brought about by the people intervention toward a nature. It has been assumed that people personality and intelligent influence the ecosystem. That is why the objective of this study is to find out relationship between knowledge about issues (KAI) and Locus of Control (LOC) with citizenship behavior (CB). In order meet with this objective, a survey method has been applied by involving 110 students as sample. There are three instruments, measuring knowledge about climate change issues, LOC, and students' citizenship behavior (CB) and those have been validated. Regression and correlational analysis used to verify it relationship. Research results reveal that there is positive and significant correlation between knowledge about issues and $C B, L O C$ and $C B$, finally between knowledge about issues and $L O C$ with $C B$. These findings are still consistent even though first order correlation can be used to predict student's citizenship behavior in term of how student live with nature harmoniously based on knowledge about issues and LOC. It could be concluded that in improving citizenship behavior, knowledge about issues and LOC cannot be neglected.
\end{abstract}

Keywords: knowledge about issues, locus of control, and citizenship behavior. 


\section{Pendahuluan}

Dalam tatanan perkembangan global dunia, perubahan merupakan sesuatu yang harus dihadapi oleh kita semua. Perubahan yang beriringan dengan ruang dan waktu, akan membawa konsekuensi logis bagi semua manusia.

Kondisi yang demikian mengimplikasi kepada seluruh kehidupan masyarakat untuk selalu menyiapkan segala sesuatu demi kehidupan dirinya dan masyarakat. Demikian juga dengan kondisi lingkungan sebagai tempat manusia melakukan proses kehidupan. Lingkungan menjadi isu global, karena lingkunganlah yang akan melangsungkan kehidupan dan dengan lingkungan pula manusia dapat melakukan aktivitas demi kehidupan dirinya dan masyarakat.

Perubahan iklim atau climate change merupakan perubahan signifikan jangka panjang cuaca rata-rata yang dialami suatu tempat. Cuaca rata-rata termasuk temperatur rata-rata, curah hujan rata-rata, dan pola badai. Team SOS Pemanasan Global Solusi dan Peluang Bisnis mengatakan perubahan ini bisa terjadi karena proses alam dan juga akibat kegiatan manusia yang kurang bertanggung jawab kepada lingkungan.

Sebelumnya orang menduga masalah lingkungan global lebih banyak dipengaruhi faktor alam, seperti iklim, yang mencakup temperatur, curah hujan, kelembaban, tekanan udara dan lain-lain. Belakangan orang mulai menyadari bahwa aktivitas manusia pun mempengaruhi iklim dan lingkungan secara signifikan misalnya, penebangan hutan yang mempengaruhi perubahan suhu dan curah hujan.

Implikasi dari perubahan iklim begitu luas terhadap kehidupan manusia. Sehingga seluruh kalangan harus segera memulai upaya untuk mengatasinya.Akar permasalahannya umumnya disebabkan oleh perilaku bijak seseorang terhadap lingkungan (citizenship behavior).
Jadi sebelum seseorang mampu bertindak dengan sengaja terhadap masalah-masalah lingkungan seperti perubahan iklim, dia harus mampu mengetahui (be cognizant) eksistensi isu perubahan iklim. Jadi pengetahuan tentang isu muncul sebagai syarat awal terjadinya perilaku (action). Seseorang harus juga memiliki kemampuan dan pengetahuan tentang tindakan yang tersedia dan yang akan sangat efektif pada situasi tertentu.

Berdasarkan fakta-fakta yang telah dijelaskan, untuk meningkatkan perilaku bijak terhadap lingkungan (citizenship behavior) dalam hal ini adalah pengetahuan tentang isu perubahan iklim dan locus of control (loc) menjadi suatu keharusan yang dimiliki dan ditingkatkan oleh siswa dalam rangka menciptakan kondisi lingkungan yang bersih dan nyaman.

Hollweg mengatakan bahwa perilakubijak terhadap lingkungan merupakan sumber pengalaman yang dapat digunakan untuk mendukung terbentuknya perilaku yang baru, dalam hal ini berkaitan dengan lingkungan. Iwata mendeskripsikan perilaku bijak terhadap lingkungan yang ditunjukkan oleh seseorang atau sekelompok orang seperti memanfaatkan kembali barang bekas dan menghemat energi, yang dapat membantu mengurangi masalah lingkungan global.

Perilaku bijak terhadap lingkungan (citizenship behavior) hampir sama dengan perilaku bertanggungjawab lingkungan (responsible environmental behavior). Perilaku lingkungan dimaksud antara lain: adanya perhatian tentang masalah-masalah pencemaran lingkungan, mencintai linkungan dan mendukung kebijakan lingkungan, memakai produk ramah lingkungan, dan penghematan energi. Bentuk perilaku tersebut, menunjukkan upaya memelihara kondisi lingkungan agar tetap stabil sehingga tercapai keberlanjutan kualitas 
lingkungan.

Pengetahuan isu perubahan iklim adalah hasil proses berpikir dan pengalaman seseorang dengan cara berinteraksi secara terus-menerus dengan lingkungannya baik berupa sederetan informasi yang berkaitan dengan berbagai obyek yang diamati dan diklasifikasikan dalam bentuk fakta, konsep, prosedur, dan metakognitif tentang isu perubahan iklim. Isu perubahan iklim tersebut antara lain mengenai pemanasan global (Global Warming), penipisan ozon, dan hujan asam.

Locus of control (loc) adalah karakteristik seseorang terhadap dirinya sendiri tentang sifat yang dimilikinya berkaitan dengan keberhasilan dan kegagalan yang dihadapinya, bila keberhasilan dan kegagalan dianggap disebabkan oleh dirinya sendiri maka sifat seseorang termasuk locus of control internal, bila keberhasilan dan kegagalan dianggap disebabkan oleh luar dirinya sendiri maka sifat seseorang termasuk locusof control eksternal.

\section{Metodologi Penelitian}

Berdasarkan perumusan masalah yang telah dikemukakan maka secara khusus tujuan penelitian ini adalah: (1) Untuk mengetahui hubungan antara pengetahuan tentang isu perubahan iklim dengan perilaku bijak terhadap lingkungan (citizenship behavior); (2) Untuk mengetahui hubungan antara locus of control dengan perilaku bijak terhadap lingkungan (citizenship behavior); (3) Untuk mengetahui hubungan antara pengetahuan tentang isu perubahan iklim dan locus of control secara bersamasama dengan perilaku bijak terhadap lingkungan (citizenship behavior).

Penelitian ini merupakan penelitian kuantitatif dengan metode korelasional dan dilakukan di SMA
Negeri 1 Jakarta (SMA Budi Utomo). Populasi dalam penelitian ini, dibedakan menjadi dua kelompok yaitu populasi target dan populasi terukur. Populasi target dalam penelitian ini adalah siswasiswa di DKI Jakarta. Sedangkan populasi terukur dalam penelitian ini adalah siswa-siswa di SMA Negeri 1 Jakarta yang ditentukan secara multistage sampling dengan jumlah 110 siswa.

Untuk mengumpulkan data dalam penelitian ini, peneliti menggunakan kuesioner dan tes. Teknis analisis data dipersyaratkan untuk menguji hipotesis penelitian ini yaitu: (1) Teknis Analisis Deskriptif, dilakukan untuk mencari skor rata-rata, simpangan baku, distribusi frekuensi, modus, median serta histogram dari skor perilaku bijak lingkungan (citizenship behavior), skor pengetahuan isu perubahan iklim, dan locus of control; (2) Analisis inferensial menggunakan analisis regresi dan korelasi. Sebelumnya dilakukan analisis berupa uji normalitas galat taksiran dan homogenitas varian $\mathrm{Y}$ dan $\mathrm{X}(\mathrm{X} 1$ dan $\mathrm{X} 2$ ).

\section{Hasil Penelitian Dan Pembahasan}

Penelitian ini melibatkan tiga variabel, yaitu Perilaku Bijak terhadap Lingkungan (Citizenship Behavior) (Y) sebagai variabel terikat, sedangkan Pengetahuan tentang Isu Perubahan Iklim $\left(\mathrm{X}_{1}\right)$ dan Locus of Control $\left(\mathrm{X}_{2}\right)$ adalah variabel bebas. Adapun secara rinci pembahasan hasil analisis dan pengujian hipotesis penelitian diuraikan sebagai berikut:

1. Hubungan antara Pengetahuan tentang Isu Perubahan Iklim $\left(X_{1}\right)$ dengan Perilaku Bijak terhadap Lingkungan (Citizenship Behavior) (Y)

Hipotesis pertama yang diajukan dalam penelitian ini adalah terdapat 
hubungan positif antara pengetahuan tentang isu perubahan iklim $\left(\mathrm{X}_{1}\right)$ dengan perilaku bijak terhadap lingkungan (citizenship behavior) (Y). Adapun besarnya koefisien korelasi antara variabel $\mathrm{X}_{1}$ dengan $\mathrm{Y}$ dapat dilihat pada tabel 1 berikut ini:

Tabel 1

Hubungan antara $X_{1}$ dengan $Y$

\begin{tabular}{|c|c|c|c|c|}
\hline Hubungan & $\mathbf{n}$ & $r_{x y l}$ & $t_{\text {hitung }}$ & $\begin{array}{c}\text { tabel } \\
\alpha=0.05\end{array}$ \\
\hline \begin{tabular}{ll|}
\multicolumn{2}{l|}{ Pengetahuan } \\
tentang Isu \\
Perubahan \\
Iklim $\quad\left(\mathrm{X}_{1}\right)$ \\
dengan \\
Perilaku \\
terhadajak \\
Lingkungan \\
(Y) \\
\end{tabular} & 110 & 0.612 & $8.05 * *$ & 1.67 \\
\hline
\end{tabular}

Keterangan

$* *=$ Korelasi sangat signifikan ( $t_{\text {hitung }}>\mathrm{t}_{\text {tabel }}$ ) pada $\alpha=0.05$

Dari hasil perhitungan antara pengetahuan tentang isu perubahan iklim dengan perilaku bijak terhadap lingkungan (citizenship behavior) ditunjukkan koefisien korelasi Product Moment sebesar $\mathrm{r}_{\mathrm{x} 1 \mathrm{y}}=0,612$ dan diuji keberartian koefisien korelasi dengan uji $\mathrm{t}$ diperoleh $\mathrm{t}_{\text {hitung }}=8$,05dengan harga $t_{\text {tabel }}$ dengan $\mathrm{dk}=108$ dan taraf signifikan $\alpha=0,05$ diperoleh nilai 1,67. Karena $t_{\text {hitung }}=8,05>t_{\text {tabel }}=1,67$ dapat disimpulkan bahwa $\mathrm{H}_{0}$ ditolak.

Temuan ini menyimpulkan terdapat hubungan positif antara pengetahuan tentang isu perubahan iklim dengan perilaku bijak terhadap lingkungan (citizenship behavior). Dengan kata lain makin tinggi pengetahuan tentang isu perubahan iklim maka makin baik perilaku bijak terhadap lingkungan (citizenship behavior).

2. Hubungan antara Locus of $\operatorname{Control}\left(\mathrm{X}_{2}\right)$ dengan Perilaku Bijak

\section{terhadap Lingkungan (Citizenship Behavior) (Y)}

Hipotesis kedua yang diajukan dalam penelitian ini adalah terdapat hubungan positif antara locus of $\operatorname{control}\left(\mathrm{X}_{2}\right)$ dengan perilaku bijak terhadap lingkungan (citizenship behavior) (Y). Adapun besarnya koefisien korelasi antara variabel $\mathrm{X}_{2}$ dengan $\mathrm{Y}$ dapat dilihat pada tabel 2 berikut ini:

Tabel 2

\section{Hubungan antara $X_{2}$ dengan $Y$}

\begin{tabular}{|c|l|l|l|l|}
\hline \multicolumn{1}{|c|}{ Hubungan } & $\mathbf{N}$ & $\mathbf{r}_{\mathbf{x y 2}}$ & thitung & $\begin{array}{l}\text { ttabel } \boldsymbol{\alpha} \\
\mathbf{0 . 0 5}\end{array}$ \\
\hline $\begin{array}{l}\text { Locus of Control }\left(\mathrm{X}_{2}\right) \\
\text { dengan Perilaku Bijak }\end{array}$ & 110 & 0.575 & $\nabla .31^{* *}$ & 1.67 \\
$\begin{array}{l}\text { terhadap Lingkungan } \\
(\mathrm{Y})\end{array}$ & 1.67 & & \\
\hline
\end{tabular}

Keterangan :

$* *=$ Korelasi sangat signifikan $\left(\mathrm{t}_{\mathrm{hitung}}>\right.$ $\left.t_{\text {tabel }}\right)$ pada $\alpha=0.05$

Dari hasil perhitungan antara locus of control dengan perilaku bijak terhadap lingkungan (citizenship behavior) ditunjukkan koefisien korelasi Product Moment sebesar $\mathrm{r}_{\mathrm{x} 2 \mathrm{y}}$ $=0,575$ dan diuji keberartian koefisien korelasi dengan uji $\mathrm{t}$ diperoleh $\mathrm{t}_{\text {hitung }}=$ 7,31 dengan harga $t_{\text {tabel }}$ dengan $\mathrm{dk}=$ 108 dan taraf signifikan $\alpha=0,05$ diperoleh nilai 1,67. Karena $t_{\text {hitung }}=$ 7,31> $\mathrm{t}_{\text {tabel }}=1,67$ dapat disimpulkan bahwa $\mathrm{H}_{0}$ ditolak.

Temuan ini menyimpulkan terdapat hubungan positif antara locus of control dengan perilaku bijak terhadap lingkungan (citizenship behavior). Dengan kata lain makin internal locus of control maka makin baik perilaku bijak terhadap lingkungan (citizenship behavior). 
locus of control dengan perilaku bijak terhadap lingkungan (citizenship behavior) ditunjukkan dengan nilai koefisien $r_{\mathrm{x} 2 \mathrm{y}}=0,575$.

Ketiga, pengujian hipotesis ketiga menyimpulkan bahwa terdapat hubungan positif antara pengetahuan tentang isu perubahan iklim dan locus of control secara bersama-sama dengan perilaku bijak terhadap lingkungan (citizenship behavior) yang ditunjukkan nilai $F_{\text {hitung }}=55,56$ lebih besar dari $\mathrm{F}_{\text {tabel }}=3,09(\alpha=0,05$ diperoleh; $\mathrm{dk}=107$ ).

\section{Kesimpulan}

Hasil analisis korelasional menunjukkan bahwa pengujian hipotesis yang telah dilakukan menunjukkan bahwa ketiga hipotesis yang diajukan dalam penelitian ini, diterim atau signifikan. Sehingga dari hasil pengujian tersebut dapat disimpulkan sebagai berikut: (1) terdapat hubungan positif antara pengetahuan tentang isu perubahan iklim dengan perilaku bijak terhadap lingkungan (citizenship behavior); (2) terdapat hubungan positif antara locus of control dengan perilaku bijak terhadap lingkungan (citizenship behavior); dan (3) terdapat hubungan positif antara pengetahuan tentang isu perubahan iklim dan locus of control secara bersama-sama dengan perilaku bijak terhadap lingkungan (citizenship behavior).

\section{Daftar Pustaka}

Budi Susetyo. Prosedur Penyusunan dan Analisis Tes.Bandung: Refika Aditama, 2015.

Disaptono.Sebuah Kumpulan Pemikiran: Mitigasi Bencana dan Adaptasi Perubahan Iklim (Gempa Bumi, Tsunami, Banjir, Abrasi,
Pemanasan Gobal, dan Semburan Lumpur Lapindo). Jakarta[ID]: Kementrian Kelautan dan Perikanan, 2011.

Dwi Kurniawati. 'Isu Lingkungan (Pemanasan Global)' [online]. https://dwikurniawati24.wordpress. com/lingkungan/isulingkungan_pe manasan-global/> [diakses :20Februari 2016]

Eko Putro Widoyoko. Penilaian Hasil Pembelajaran $d i$ Sekolah.Yogakarta: Pustaka Pelajar, 2014.

E.M. Dijkstra \& M.J. Goedhart, development and validation of the ACSI: measuring student's science atittudes, pro-environmental behavior, climate change attitudes and knowledge.Environmental Education Research, Vol. 18, issue 6, 2012 (diakses : 1 Agustus 2016)

Francis J.DI Vesta dan George G. Thomson. Educational Psychology : Instruction and Behavioral Change.New York: Appleton Century Crofts, 1970.

G.Terry J.B Thomas \& A.R Marshall.International Dictionary of Education dalam Hamzah B.Uno Jakarta: Ina Publimatika, 2014.

Gregory Moorhead and Ricky W. Griffin.Managing Organizational Behavior .United State : McGrawHill, 2012.

Hines, J.M., Hongerford, H.R., \& Tomera, A.N. Analysis and synthesis of research on responsible environmental behavior : A meta-anaysis. Journalof Environmental Education. Vol. 18 (2), 1986.

Hollweg, K.S.,et.al. Developing a Framework for Assesing Environmental Literacy. Washington, DC : North American Association for Environmental Education, 2011. 
I Made Putrawan.“Konsep-Konsep Dasar Ekologi Dalam Berbagai Aktivitas Lingkungan" Alfabeta: Bandung, 2014.

Jason A. Colquitt, Jeffery A. LePine, dan Michael J. Wesson. Organizational Behavior .New York: McGraw-Hill, 2009.

Jason A.Colquit, Jeffery A.Lepine \& Michael J.Wesson.Organizational Behavior Improving Performance and Commitment in the Workplace, second edition.New York: McGraw-Hill, 2011.

John R. Schermerhon et.al. Organizational Behavior International Student Version .Asia : Jhon Wiley \& Sons, Inc, 2012.

John W. Santrock. Educational Psychology. University of Texas at Dallas Pulb : McGraw-Hill, 2009.

Julian B. Rotter. Educational Psychology.New York: McGrawHill, 1996.

W. Lorin Anderson \& David R.A Taxonomy for Learning, Teaching, and Assesing , A Reversion of Blomm's Taxonomy of Educational objectives.New York: Addison Wesley Logman, Inc, 2001.

Luthan Fred.Organizational Behavior.New York: McGraw-Hill, 2008.

MsChane.Organizational

Behavior.Singapore: by McGrawHill Education, 2013.

Mulayadi. Effect of Environmental Knowledge, Local Wisdom, Locus of Control and Farming Motivation on Responsible Environmental Behavior of Farmers in Soppeng Regency of South Sulawesi.International Journal of Academic Research, Vol.3.2 March 2011, p.101. [diakses : 14 Mei 2016]
Robert Kreitner and Angelo Kinicki. Organizational Behavior. McGraw Hill Companies, Inc, 2008.

Stephen P. Robbins and Thimothy A.Judge.Organizational

Behavior.New Jarsey : Pearson Education, Inc, 2011. 


\begin{tabular}{|l|l|l|l|}
\hline Volume XVIII & Nomor 01 & Maret 2017 & ISSN 1411-1829 \\
\hline
\end{tabular}

